\title{
List of plates
}

I Méliès gets a swelled head in L'Homme à la tête en caoutchouc, I9OI

2 The Baron wakes from uneasy dreams in Les Hallucinations de Baron de Munchausen, I9II

5 Guards find Henry's suicide note in L'Affaire Dreyfus (Episode 5, Le suicide du colonel Henry), I899

6 A rising star in L'Eclipse du soleil en pleine lune, I907 86

7 State-of-the-art rocket launch in Le Voyage dans la lune, I902 86

8 A fairy; dangling corpses - two kinds of flying women in Barbe-bleue, I901

9 A soldier gets in over his head in Le Royaume des fées, I903 87

Io The phantom coach in Les Quat' cents farces du diable, I906 88

II The French take a break from working on the Channel Tunnel in Le Tunnel sous la Manche, I907

Plates I-4, 6 and 8-II were supplied by and are reproduced with permission from the Museum of Modern Art, New York; plates 5 and 7 were supplied by and are reproduced with permission from the Collection Roger-Viollet. 